\title{
Milk immunoglobulins and complement factors
}

\author{
Hannu Korhonen $^{1}$, P. Marnila ${ }^{1}$ and H. S. Gill ${ }^{2}$ \\ ${ }^{1}$ Agricultural Research Centre of Finland, Food Research, FIN-31600 Jokioinen, Finland \\ ${ }^{2}$ Milk and Health Research Centre, Massey University and New Zealand Dairy Research Institute, Private Bag 11 222, \\ Palmerston North, New Zealand
}

\begin{abstract}
The importance of colostrum for the growth and health of newborn offspring is well known. In bovine colostrum, the antibody (immunoglobulin) complement system provides a major antimicrobial effect against a wide range of microbes and confers passive immunity until the calf's own immune system has matured. Bovine serum and lacteal secretions contain three major classes of immunoglobulins: IgG, IgM and IgA. The immunoglobulins are selectively transported from the serum into the mammary gland, as a result of which the first colostrum contains very high concentrations of immunoglobulins (40-200 mg/ml). IgG1 accounts for over $75 \%$ of the immunoglobulins in colostral whey, followed by $\operatorname{IgM}, \operatorname{IgA}$ and $\operatorname{IgG} 2$. All these immunoglobulins decrease within a few days to a total immunoglobulin concentration of $0.7-$ $1.0 \mathrm{mg} / \mathrm{ml}$, with $\mathrm{IgG} 1$ representing the major Ig class in milk throughout the lactation period. Together with the antibodies absorbed from colostrum after birth, the complement system plays a crucial role in the passive immunisation of the newborn calf. The occurrence of haemolytic or bactericidal complement activity in bovine colostrum and milk has been demonstrated in several studies. This review deals with the characteristics of bovine Igs and the complement system to be exploited as potential ingredients for health-promoting functional foods.
\end{abstract}

Milk: Colostrum: Immunoglobulins: Complement: Antimicrobial activity

\section{Introduction}

The unique significance of milk and colostrum to the health and growth of newborn mammals is well documented (Brambell, 1969; Butler, 1974, 1986, 1994; Larson, 1992; Quigley \& Drewry, 1998). In the 1890s, Paul Ehrlich proposed that colostrum was a vehicle for transporting immune factors, 'antikörpern', from the mother to her offspring (Ehrlich, 1892). Since then, the species-specific differences in the mechanism of the transfer of passive immunity to the newborn have been clearly demonstrated. In humans, for example, maternal immunoglobulins (Ig) with specific antimicrobial activity are transferred via the placenta to the newborn infant, and can confer a degree of passive immunity (Goldman, 1993). On the other hand, in other species such as pigs, horses, sheep and cows, Igs are only transferred postnatally via colostrum, as the placenta does not allow significant transfer of macromolecules (Butler, 1994). A selective accumulation of Igs from the blood circulation into the colostrum starts several weeks before parturition. In a newborn calf, the Igs are absorbed from the colostrum into the circulation within $24-36 \mathrm{~h}$ after birth via a non-selective macromolecular transport system (McFadden et al. 1997). This knowledge has been utilised for the development of commercial supplements containing Igs and complement factors concentrated from bovine colostrum or whey (Haines et al. 1990; Nousiainen et al. 1994; Mee \& Mehra, 1995). In addition, the possibility of isolating bovine colostral Igs from cows, following immunisation against pathogens, has been investigated as a potential strategy for the prevention and treatment of gastrointestinal diseases in humans. This article reviews the physico-chemical, biochemical, immunological and technological characteristics of bovine Igs and the complement system.

\section{Characteristics of immunoglobulins}

Bovine serum and lacteal secretions contain three major classes of Igs: IgG, IgM and IgA. The basic structure of all Igs is similar, and is composed of two identical light chains $(23 \mathrm{kDa})$ and two identical heavy chains $(53 \mathrm{kDa})$. These four chains are joined together with disulphide bonds. The complete Ig or 'antibody' molecule has a molecular weight of about $180 \mathrm{kDa}$. The two identical antigen-binding sites are formed by the N-terminal part of one heavy and one light chain. The bovine IgG molecule occurs predominantly in two subclasses: IgG1 and IgG2. Monomeric IgM and IgA have a similar basic structure to IgG except for the addition of a C-terminal octapeptide to the heavy chains. IgA occurs as a monomer or dimer, the latter comprising

\footnotetext{
* Corresponding author: Hannu Korhonen, fax +358-3-4188 3244, email hannu.j.korhonen@mtt.fi
} 
two $\operatorname{IgA}$ molecules joined together by a J-chain and a secretory component. This complex is called secretory IgA (SIgA) and has a molecular weight of about $380 \mathrm{kDa}$. Except for ruminant lacteal secretions, IgA is the dominating Ig in all external secretions of the body. IgM consists of five subunits, similar to monomeric $\operatorname{IgA}$, which are linked together in a circular mode by disulphide bonds and a $\mathrm{J}$ chain; the molecular weight of pentameric $\operatorname{IgM}$ is approximately $900 \mathrm{kDa}$.

The concentration of the various bovine Igs in serum and in lacteal secretions varies according to the breed, age, health status, and stage of lactation of the animal (Butler, 1986, 1994; Larson, 1992; McFadden et al. 1997). In colostrum, Igs make up $70-80 \%$ of the total protein content, whereas in mature milk, immunoglobulins account for only 1-2\% of the protein (Larson, 1992). In serum, both IgG subclasses are present at about equal concentrations (IgG1 $11.2 \mathrm{mg} / \mathrm{ml}, \operatorname{IgG} 29.2 \mathrm{mg} / \mathrm{ml}$ ), whereas IgM and IgA occur at concentrations of about $3.0 \mathrm{mg} / \mathrm{ml}$ and $0.4 \mathrm{mg} / \mathrm{ml}$, respectively (Butler, 1994). After the cessation of lactation, the IgG1 accumulates selectively from the blood circulation into the colostrum by an active receptormediated transfer across the mammary gland secretory epithelium. This process results in a 5- to 10-fold increase in the concentration of IgG1 in colostrum compared to maternal serum (Butler, 1983; Besser \& Gay, 1994). It has been suggested that approximately 50-100 g per day or up to $500 \mathrm{~g}$ per week of IgG1 may be transferred from the blood into the mammary secretions during colostrum formation (Brandon \& Lascelles, 1971). The concentration of Igs can vary considerably, from 30 to $200 \mathrm{mg} / \mathrm{ml}$, in the first colostrum (Kruse, 1970; Korhonen et al. 1977; Stott et al. 1981; Hancock 1985; Larson, 1992; Korhonen et al. 1995). IgG1 comprises over $75 \%(46.4 \mathrm{mg} / \mathrm{ml})$ of the Igs in colostral whey, followed by $\operatorname{IgM}(6.8 \mathrm{mg} / \mathrm{ml})$, IgA $(5.4 \mathrm{mg} / \mathrm{ml})$ and $\operatorname{IgG} 2(2.9 \mathrm{mg} / \mathrm{ml})$ (Butler, 1994). The total Ig levels in milk decline rapidly following parturition to around $0.7-1.0 \mathrm{mg} / \mathrm{ml}$. IgG1, however, remains the predominant Ig subclass in these secretions.

The Igs are produced by B lymphocytes. All Igs exhibit one or more effector function in addition to antigen binding. Whereas one part of an antibody (Fab) binds to antigen, other parts (mostly the Fc region) interact with other elements. In effect, antibodies function as flexible adaptors linking various parts of the immune system. The immunological function mediated by the Igs depends on the Ig class. IgG antibodies have a multitude of functions, the most important of which is possibly the activation of complement-mediated bacteriolytic reactions. Another vital function of Igs is their ability to augment the recognition and phagocytosis of bacteria by leucocytes (opsonisation). Igs are also able to prevent the adhesion of microbes to surfaces, inhibit bacterial metabolism, agglutinate bacteria, and neutralise toxins and viruses. IgM antibodies, although produced in smaller amounts than $\mathrm{IgG}$, are considerably more efficient than $\mathrm{IgG}$ with regard to most of the above activities, especially complementmediated lysis. IgA, in contrast, does not fix complement or opposing bacteria, but agglutinates antigens, neutralises viruses and bacterial toxins, and prevents the adhesion of enteropathogenic bacteria to mucosal epithelial cells. The secretory piece component of the $\operatorname{IgA}$ molecule makes it resistant to the activities of proteolytic digestive enzymes. In humans, this property is manifested by the passage of a considerable proportion of undigested active IgA from human colostrum through the gut of the neonate baby (Goldman, 1993). In comparison, many in vitro studies have shown that bovine $\mathrm{IgG}$ is also relatively resistant to proteolysis by digestive enzymes and is not inactivated by gastric acid (de Rham \& Isliker, 1977; Brock et al. 1978; McClead \& Gregory, 1984); e.g. about $10 \%$ of intact IgG and virus neutralising $\mathrm{F}(\mathrm{ab})_{2}$ fragments were detected in the faeces of newborn babies who were given bovine Ig concentrates orally (Zinkernagel et al. 1972; Hilpert et al. 1987). Using ${ }^{15} \mathrm{~N}$-labelled Igs isolated from bovine colostrum, Roos et al. (1995) demonstrated that about $19 \%$ of ingested $\operatorname{IgG}$ and $\operatorname{IgM}$ was found to retain immunological activity in the ileum of healthy human adults. Kelly et al. (1997) measured the survival of orally administered bovine immunoglobulin concentrate against Clostridium difficile toxins in the human gastrointestinal tract. Without encapsulation the mean faecal bovine $\mathrm{Ig}$ content of three-day stools was $1.6-3.8 \%$ of the administered Ig, whereas Ig administered in enteric capsules resulted in a $32.7 \%$ recovery in faeces. Thus, an appropriate delivery system and the controlled release of Igs in a desired part of the gastrointestinal tract are likely to play a crucial role in the pharmacological efficacy of the Igs ingested.

\section{Commercial isolation of Igs}

Since the 1980s, a number of patented methods have been developed for the isolation and purification of Igs from colostral or cheese whey, based on ultrafiltration (UF) or a combination of UF and chromatography (Kothe et al. 1987; Abraham, 1988; Stott \& Lucas, 1989; Korhonen et al. 1998). For the commercial production of crude $\mathrm{Ig}$ preparations, a combination of different membrane technologies seems to be the most cost-effective approach. However, for the improvement of the recovery rate of Igs from whey and to increase the Ig concentration of the final preparation, specific chromatographic techniques need to be applied. For example, the separation of $\mathrm{IgG}$ from UFtreated whey has been successful using immobilised metal chelate chromatography (Al-Mashikhi et al. 1988; Fukumoto et al. 1994a), whereas the most suitable process for the isolation of bovine IgG subclasses IgG1 and IgG2 is an immunoaffinity chromatography process using immobilised egg yolk antibodies (Akita \& Li-Chan, 1998).

The effects of processing and storage conditions on the stability of purified Igs or Ig concentrates have been the subject of many recent studies. During processing, the stability of the Ig activity in colostrum or milk is influenced by thermal treatment (Lindström et al. 1994; Li-Chan et al. 1995; Dominguez et al. 1997). Following high temperature/ short time (HTST) pasteurisation $\left(72^{\circ} \mathrm{C} / 15 \mathrm{~s}\right)$ only 10 $30 \%$ of the Ig activity is lost, whereas ultrahigh temperature (UHT) treatment $\left(138^{\circ} \mathrm{C} / 4 \mathrm{~s}\right)$ and evaporation processing destroys the majority of the specific immune activity of milk (Kummer et al. 1992; Li-Chan et al. 1995). The rapid heat inactivation of $\mathrm{IgG}$ starts at temperatures 
higher than $65^{\circ} \mathrm{C}$, and at $81^{\circ} \mathrm{C}$, as much as $90 \%$ of the virus neutralisation activity is lost in less than two minutes (Mainer et al. 1999). However, bovine IgG added to UHT milk has been shown to retain its specific immune activity for over several months (Fukumoto et al. 1994b; Virtanen et al. 1998). Also, Ig molecules seem to retain their specific activity well in milk powder, irrespective of the storage temperature; the storage of freeze-dried anti-Campylobacter jejuni Igs at 4,20 and $37^{\circ} \mathrm{C}$ has been found to have little effect on the immune specificity for up to 12 months of storage (Husu et al. 1993).

\section{Characteristics of the complement system}

The complement system plays a major role in the hostdefence mechanisms against infectious microbes, as it is involved both in specific and non-specific immunity. It is a complex system of over 20 different proteins that can be activated by antigen-antibody complexes (classical pathway), by certain carbohydrates (lectin pathway), or by a variety of surfaces that are not protected by natural inhibitors (alternative pathway). Killing of micro-organisms, clearing of immune complexes, and induction and enhancement of antibody responses are the major biological functions of complement (Brown et al. 1983; Tabel, 1996; Fearon, 1998). The classical pathway is initiated by the activation of the first, and the alternative pathway by the third complement protein in a cascade order. Because of the enzymatic capabilities of several components of this cascade, such activation leads to a strong amplification of the reactions. Activation by the classical pathway is mainly initiated by binding of the first component to antigenantibody complexes or directly to certain microbes. In the absence of antibodies the complement activation occurs by lectins bound to pathogen surfaces via the lectin pathway (Holmskov \& Jensenius, 1996; Turner, 1996) or the alternative pathway, which is initiated in the presence of bacterial cell membrane components such as lipopolysaccharides or $\beta$-glucan. Activation by any of the pathways leads to the enzymatic cleavage of the third $(\mathrm{C} 3 \mathrm{~b})$ and the fifth (C5) components of complement, generating the cleavage products $\mathrm{C} 3 \mathrm{a}, \mathrm{C} 3 \mathrm{bi}, \mathrm{C} 5 \mathrm{a}$ and $\mathrm{C} 5 \mathrm{~b}$. These products are responsible for most of the biologically important functions of the system (Janeway, 1997). For example, $\mathrm{C} 3 \mathrm{~b}, \mathrm{C} 3 \mathrm{bi}, \mathrm{C} 4 \mathrm{~b}$ and perhaps also C1q function as opsonins augmenting phagocytosis, thus helping the clearance and destruction of bacteria and immune complexes. The small anaphylatoxins $\mathrm{C} 3 \mathrm{a}, \mathrm{C} 4 \mathrm{a}$ and $\mathrm{C} 5 \mathrm{a}$ recruit inflammatory leucocytes to the sites of an inflammation and activate their effector mechanisms. They are also involved in mast cell and basophil-mediated inflammatory reactions such as vascular dilation. In the latter part of the complement reaction, cascade $\mathrm{C} 5 \mathrm{~b}$ associates with components $\mathrm{C} 6, \mathrm{C} 7$, C8 and multiple C9. Polymeric C9 forms a channel (membrane attack complex, MAC) in the bacterial cell membrane, leading to the leakage of electrolytes, collapse of metabolism and subsequent death of the cell (Born \& Bhakdi, 1986). Most Gram-negative bacteria are sensitive to the lytic action of complement, but all Gram-positive and some Gram-negative bacteria are resistant and, therefore, more virulent (Rautemaa \& Meri, 1999). However, both
Gram-positive and Gram-negative bacteria can become opsonised by $\mathrm{C} 3 \mathrm{~b}$ and $\mathrm{C} 3 \mathrm{bi}$, and opsonophagocytosis is thus the main defence mechanism against bacteria resistant to complement lysis (Rautemaa \& Meri, 1999).

Apart from its direct antimicrobial effects, complement maintains the antibodies in soluble form by limiting the formation of harmful immune complexes and inhibiting the precipitation of Igs. The Ig-complexes are opsonised with $\mathrm{C} 3 \mathrm{~b}$ protein following complement activation, and removed by the tissue macrophages mainly in the liver and spleen. In effect, the ability to keep immune complexes soluble by reducing the number of antigen epitopes that the antibodies can bind is one of the main tasks of the classical complement pathway. Complement can also rapidly resolubilise the precipitated Ig complexes through the alternative pathway. The resolubilisation occurs by the insertion of $\mathrm{C} 3 \mathrm{~b}$ and $\mathrm{C} 3 \mathrm{~d}$ into the complexes (Walport, 1996).

Complement activity is known to occur in the serum of fetal calves (Triglia, 1980; Mueller et al. 1983). Together with the antibodies absorbed from colostrum after birth, the complement system plays a crucial role in providing passive immunity to the newborn calf (Butler, 1986; Staak, 1992). Apart from serum, the complete complement system can be found in bovine colostrum, and components of the system are present in milk. Several studies have demonstrated the occurrence of haemolytic or bactericidal complement activity in bovine colostrum (Brock et al. 1975; Reiter \& Brock, 1975; Eckblad et al. 1981; Korhonen et al. 1995). Compared to normal milk whey, the concentration of $\mathrm{C} 3$ and haemolytic activity are elevated in the milk whey from mastitic cows, but the values do not reach the level present in blood serum (Muller et al. 1982; Rainard et al. 1984). Also, conglutinating activity, indicating the presence of complement components $\mathrm{C} 1,4,2,3$ has been found irregularly in milk of mid and late lactation (Reiter \& Oram, 1967; De Cueninck, 1979). It is doubtful whether the active complement system found in colostrum is effective in vivo against bacterial infections in the gut of the newborn calf, since the bactericidal activity of colostrum can be readily destroyed by trypsin or pancreatic juice. However, it has been demonstrated experimentally that the loss of complement bioactivity due to trypsin can be prevented by the addition of excess bovine colostral trypsin inhibitor (Brock et al. 1975). This enzyme is known to occur naturally in colostrum (Pineiro et al. 1975).

\section{Antibody-related antimicrobial activity of colostrum and milk}

Bovine colostrum and milk are known to contain a large number of naturally occurring antimicrobial substances (Reiter, 1985; IDF, 1991; Pakkanen \& Aalto, 1997; Regester et al. 1997). Among them, the antibody-complement system is considered as the major agent of the antimicrobial activity of colostrum. The antibody-augmented bactericidal activity of complement has been demonstrated in normal or immune colostrum and serum but not always in milk samples against a great number of Gramnegative bacteria, e.g. Aerobacter aerogenes (Carroll \& Jain, 1969), coliform (Carroll, 1974), enterotoxigenic 
Escherichia coli (Reiter \& Brock, 1975), Campylobacter jejuni (Husu et al. 1993; Syväoja et al. 1994) and Helicobacter pylori (Korhonen et al. 1995). The mode of the antimicrobial action in colostrum is not clearly defined. In a study by Korhonen et al. (1995), all colostrum samples derived from normal healthy cows were naturally bactericidal against $H$. pylori, whereas none of the milk samples from the same animals showed bactericidal activity. In contrast, bactericidal activity was detected in $43 \%$ of the milk samples obtained from cows hyperimmunised prepartum with a $H$. pylori vaccine. The latter fact clearly demonstrates that the antibacterial activity of milk can be increased by systemic immunisation of cows against a defined pathogen, although in that case the bactericidal activity did not correlate with titres of specific Ig or with total IgG concentrations. Previous reports had demonstrated that the bactericidal property of immune colostrum against complement-sensitive pathogens is associated with a rise in the titre of pathogen-specific Igs (Korhonen et al. 1994; Syväoja et al. 1994). In addition, certain clinical conditions may predispose the cow to produce enhanced endogenous antimicrobial activity. For example, when compared with milk from healthy cows, the milk from mastitic cows has been shown to possess increased bactericidal activity against Aerobacter aerogenes (Jain \& Jasper, 1967) and udder-pathogenic E. coli (Korhonen, 1973; Rainard et al. 1984). In these studies, heating at $56^{\circ} \mathrm{C}$ for 30 minutes destroyed the bactericidal effect (a treatment regime that is known to inactivate the complement system).

A number of earlier studies have indicated that so-called agglutinins may inhibit the growth of certain dairy starters and cause the flocculation of milk fat globules (IDF, 1991). Later, it was shown that these agglutinins were mainly associated with IgM. The natural agglutinating activity of bovine colostrum preparations has been demonstrated against a variety of pathogenic bacteria (Stephan et al. 1990; Loimaranta et al. 1998a).

Raw and pasteurised milk from non-immunised cows has been shown to contain specific antibodies to human rotavirus (Yolken et al. 1985). Also, raw milk from nonimmunised cows contains specific Igs to lipopolysaccharides from major human pathogenic bacteria, e.g. E. coli, Salmonella enteriditis, S. typhimurium and Shigella flexneri (Losso et al. 1993). Further, natural antibodies to a colonisation factor antigen (CFA-1) of human enterotoxigenic $E$. coli have been found in normal colostrum and milk (Facon et al. 1995).The specific antibodies in the colostrum of cows immunised with human pathogens have also been found to exert a synergistic effect on the activity of nonspecific antimicrobial factors such as lactoferrin and lysozyme (Takahashi et al. 1992) as well as lactoperoxidase (Loimaranta et al. 1998b).

\section{Conclusions}

The biological function of cow's milk, and especially that of colostrum, is not only to give nourishment to the offspring but also to provide it with an immune protection against environmental pathogens. Cow's colostrum and milk contain virtually all compounds of bovine cellular and humoral immune defence, including antibodies and complement proteins. Commercial whey or colostral antibody preparations, which may also contain complement proteins, have been used for a long time as feed supplements or substitutes for farm animals, mainly calves and piglets, in order to prevent contagious diseases. These preparations have proven effective especially in the prevention of diarrhoeal diseases. Moreover, commercial products for human use have appeared on the market and a lot of scientific research work is currently under way for the application of milk antibodies in the prevention or treatment of microbial diseases in humans. Specific antibodies can be produced also in cell cultures or isolated from other body fluids than milk for use in laboratory experiments. However, thus far and in the near future those preparations are too expensive or not available for the scale of production required for commercial products. Milk and colostrum are ideal sources of these defence molecules for industrial-scale production because of their ready availability and safety as compared, for example, with bloodderived analogues. The main limitation of milk antibodies in human use is that they are derived from a foreign species and can thus be used only against oral and gastrointestinal pathogens or for topical applications. In order to overcome this limitation, it may be possible in the future to produce human antibodies and complement proteins in transgenic cows.

\section{References}

Abraham GB (1988) Process for preparing antibodies against $E$. Coli K-99 antigen from bovine milk. US Patent No 4784850, 15 Nov 1988.

Akita EM \& Li-Chan EC (1998) Isolation of bovine immunoglobulin $\mathrm{G}$ subclasses from milk, colostrum, and whey using immobilized egg yolk antibodies. Journal of Dairy Science $\mathbf{8 1}$, 54-63.

Al-Mashikhi SA, Li-Chan E \& Nakai S (1988) Separation of immunoglobulins and lactoferrin from cheese whey by chelating chromatography. Journal of Dairy Science 71, 1747-1755.

Besser TE \& Gay CC (1994) The importance of colostrum to the health of the neonatal calf. Veterinary Clinics of North America - Food Animal Practice 10, 107-117.

Born J \& Bhakdi S (1986) Does complement kill E. coli by producing transmural pores? Immunology 59, 139-145.

Brambell FW (1969) The transmission of immune globulins from the mother to the foetal and newborn young. Proceedings of the Nutrition Society 28, 35-41.

Brandon MR \& Lascelles AK (1971) Relative efficiency of absorption of $\operatorname{IgG} 1, \operatorname{IgG} 2, \operatorname{IgA}$ and $\operatorname{IgM}$ in the newborn calf. Australian Journal of Experimental Biology and Medical Science 49, 629-633.

Brock JH, Ortega F \& Pineiro A (1975) Bactericidal and haemolytic activity of complement in bovine colostrum and serum: effect of proteolytic enzymes and ethylene glycol tetraacetic acid (EGTA). Annales of Immunology (Paris) 126C, 439-451.

Brock JH, Pineiro A \& Lampreave F (1978) The effect of trypsin and chymotrypsin on the antibacterial activity of complement, antibodies, and lactoferrin and transferrin in bovine colostrum. Annales de Recherches Vèterinaires 9, 287-294.

Brown EJ, Joiner KA \& Frank MM (1983) The role of complement in host resistance to bacteria. Springer Seminars in Immunopathology 6, 349-360.

Butler JE (1974) Immunoglobulins of the mammary secretions. In 
Lactation, a Comprehensive Treatise, pp. 217-225 [BL LarsonVL Smith, editors]. Academic Press: New York.

Butler JE (1983) Bovine immunoglobulins: an augmented review. Veterinary Immunology and Immunopathology 4, 43-152.

Butler JE (1986) Biochemistry and biology of ruminant immunoglobulins. Progress in Veterinary Microbiology and Immunology 2, 1-53.

Butler JE (1994) Passive immunity and immunoglobulin diversity. In Indigenous Antimicrobial Agents of Milk-recent Developments. IDF Special Issue 9404 4, pp. 14-50.

Carroll EJ (1974) In vitro bactericidal reactions of serums and milks obtained from cows inoculated with selected serumresistant and serum-sensitive coliform bacteria. American Journal of Veterinary Research 35, 205-211.

Carroll EJ \& Jain NC (1969) Bactericidal activity of normal milk, mastitic milk, and colostrum against Aerobacter aerogenes. American Journal of Veterinary Research 30, 1123-1132.

De Cueninck BJ (1979) C 142 complement activity and conglutinogen in bovine milk. International Archives of Allergy and Applied Immunology 59, 323-327.

De Rham O \& Isliker H (1977) Proteolysis of bovine immunoglobulins. International Archives of Allergy and Applied Immunology 55, 61-69.

Dominguez E, Perez MD \& Calvo M (1997) Effect of heat treatment on the antigen-binding activity of anti-peroxidase immunoglobulins in bovine colostrum. Journal of Dairy Science 80, 3182-3187.

Eckblad WP, Hendrix KM \& Olson DP (1981) Total complement hemolytic activity of colostral whey and sera from dairy cows. Cornell Veterinarian 71, 54-58.

Ehrlich P (1892) Über Immunität durch Verebung und Zeugung. Zeitschrift für Hygiene und Infektionskrankheiten 12, 183-203.

Facon M, Skura BJ \& Nakai S (1995) Antibodies to a colonization factor of human enterotoxigenic Escherichia coli in cow's milk and colostrum. Food Research International 28, 387-396.

Fearon DT (1998) The complement system and adaptive immunity. Seminars in Immunology 10, 355-361.

Fukumoto LR, Li-Chan E, Kwan L \& Nakai S (1994a) Isolation of immunoglobulins from cheese whey using ultrafiltration and immobilized metal affinity chromatography. Food Research International 27, 335-348.

Fukumoto LR, Skura BJ \& Nakai S (1994b) Stability of membrane-sterilized bovine immunoglobulins aseptically added to UHT milk. Journal of Food Science 59, 757-759.

Goldman AS (1993) The immune system of human milk: antimicrobial, antiinflammatory and immunomodulating properties. Pediatric and Infectious Disease Journal 12, 664-671.

Haines DM, Chelack BJ \& Naylor JM (1990) Immunoglobulin concentrations in commercially available colostrum supplements for calves. Canadian Veterinary Journal 31, 36-37.

Hancock DD (1985) Assessing efficiency of passive immune transfer in dairy herds. Journal of Dairy Science 68, 163-183.

Hilpert H, Brussow H, Mietens C, Sidoti J, Lerner L \& Werchau H (1987) Use of bovine milk concentrate containing antibody to rotavirus to treat rotavirus gastroenteritis in infants. Journal of Infectious Diseases 156, 158-166.

Holmskov U \& Jensenius JC (1996) Two bovine collectins: conglutinin and CL-43. In Colletins and Innate Immunity, pp. 51-71 [RAB Ezekowitz, K Sastry and KBM Reid, editors]. Heidelberg, Springer.

Husu J, Syväoja E, Ahola-Luttila H, Kalsta H, Sivela S \& Kosunen TU (1993) Production of hyperimmune bovine colostrum against Campylobacter jejuni. Journal of Applied Bacteriology 74, 564-569.

International Dairy Federation (1991) Significance of the indigenous antimicrobial agents of milk to the dairy industry. IDF Bulletin 264, 2-19.
Jain NC \& Jasper DE (1967) Phagocytosis and destruction of Aerobacter aerogenes by leukocytes from bovine milk. American Journal of Veterinary Research 28, 405-411.

Janeway CAJ (1997) The complement system in humoral immunity. In Immunobiology: The Immune System in Health and Disease, pp. 33-35 [CAJ Janeway, P Travers, S Hunt and M Walport, editors]. London: Current Biology Ltd.

Kelly CP, Chetman S, Keates S, Bostwick E, Roush AM, Castagliolo I, Lamont JT \& Pothoulakis C (1997) Survival of anti-Clostridium difficile bovine immunoglobulin concentrate in the human gastrointestinal tract. Antimicrobial Agents and Chemotherapy 41, 236-241.

Korhonen H (1973) Untersuchungen zur Bakterizidie der Milch und Immunisierung der bovinen Milchdruse. Ph.D Thesis. Finnish Journal of Dairy Science 32, 1-158.

Korhonen H, Antila M, Halinen K \& Kouvalainen K (1977) Untersuchungen zur Erzeugung von Salmonella typhimurium Antikörpern in Milchkuhen und Herstellung von Antikörperpräparaten. Finnish Journal of Dairy Science 35, 1-28.

Korhonen H, Syväoja E-L, Ahola-Luttila H, Sivelä, S, Kopola S, Husu J, Kosunen TU (1994) Helicobacter pylori-specific antibodies and bactericidal activity in serum, colostrum and milk of immunised and non immunised cows. In Indigenous Antimicrobial Agents of Milk - Recent Developments. IDF Special Issue 9404 4, 151-163.

Korhonen H, Syväoja E-L, Ahola-Luttila H, Sivelä S, Kopola S, Husu J \& Kosunen TU (1995) Bactericidal effect of bovine normal and immune serum, colostrum and milk against Helicobacter pylori. Journal of Applied Bacteriology 78, 655-662.

Korhonen H, Syväoja E-L, Vasara E, Kosunen T \& Marnila P (1998) Pharmaceutical composition, comprising complement proteins, for the treatment of Helicobacter infections and a method for the preparation of the composition. Patentapplication PCT No. W098/00150.

Kothe N, Dichtelmuller H, Stephan W \& Echentopf B (1987) Method of preparing a solution of lactic or colostric immunoglobulins or both and use thereof. US Patent No 4644056, 17 Feb 1987.

Kruse V (1970) Yield of colostrum and immunoglobulin in cattle at the first milking after parturition. Animal Production 12, 619-626.

Kummer A, Kitts DD, Li-Chan E, Losso JN, Skura BJ \& Nakai S (1992) Quantification of bovine IgG in milk using enzymelinked immunosorbent assay. Food and Agricultural Immunology 4, 93-102.

Larson BL (1992) Immunoglobulins of the mammary secretions. In Advanced Dairy Chemistry 1-Proteins, pp. 231-254 [PF Fox, editors]. London: Elsevier Science Publishers.

Li-Chan E, Kummer A, Losso JN, Kitts DD \& Nakai S (1995) Stability of bovine immunoglobulins to thermal treatment and processing. Food Research International 28, 9-16.

Lindström P, Paulsson M, Nylander T, Elofsson U \& LindmarkMansson H (1994) The effect of heat treatment on bovine immunoglobulins. Milchwissenschaft 49, 67-70.

Loimaranta V, Carlen A, Olsson J, Tenovuo J, Syväoja E \& Korhonen H (1998a) Concentrated bovine colostral whey proteins from Streptococcus mutans/Strep. sobrinus immunized cows inhibit the adherence of Strep. mutans and promote the aggregation of mutans streptococci. Journal of Dairy Research 65, 599-607.

Loimaranta V, Tenovuo J \& Korhonen H (1998b) Combined inhibitory effect of bovine immune whey and peroxidasegenerated hypothiocyanate against glucose uptake by Streptococcus mutans. Short communication. Oral Microbiology and Immunology 13, 378-381.

Losso JN, Dhar J, Kummer A, Li-Chan E \& Nakai S (1993) 
Detection of antibody specificity of raw bovine and human milk to bacterial lipopolysaccharides using PCFIA. Food and Agricultural Immunology 5, 231-239.

McClead RE \& Gregory SA (1984) Resistance of bovine colostral anti-cholera toxin antibody to in vitro and in vivo proteolysis. Infection and Immunity 44, 474-478.

McFadden TB, Besser TE \& Barrington GM (1997) Regulation of immunoglobulin transfer into mammary secretions of ruminants. In Milk Composition, Production and Biotechnology, pp. 133-152 [DJW Welch, SR Burns, SR Davis, AI Popay and CG Prosser, editors]. Wallingford UK: CAB International.

Mainer G, Dominguez E, Randrup M, Sanchez L \& Calvo M (1999) Effect of heat treatment on anti-rotavirus activity of bovine immune milk. Journal of Dairy Research 66, 131-137.

Mee JF \& Mehra R (1995) Efficacy of colostrum substitutes and supplements in farm animals. Agro-Food-Industry Hi-Tech $\mathbf{6}$, 31-35.

Mueller R, Boothy JT, Carroll EJ \& Panico L (1983) Changes of complement values in calves during the first month of life. American Journal of Veterinary Research 44, 747-750.

Mueller R, Carroll EJ \& Panico L (1982) Complement C3 levels and haemolytic activity in normal and mastitic whey. Zentralblatt für Veterinärmedizin, Reihe B 29, 99-106.

Nousiainen J, Korhonen H, Syväoja E, Savolainen S, Saloniemi H \& Jalonen H (1994) The effect of colostral immunoglobulin supplement on the passive immunity, growth and health of neonatal calves. Agricultural Science in Finland 3, 421-427.

Pakkanen R \& Aalto J (1997) Growth factors and microbial factors of bovine colostrum. International Dairy Journal 7, 285-297.

Pineiro A, Ortega F \& Uriel J (1975) Trypsin inhibitor from cow colostrum. Isolation, electrophoretic characterization and immunologic properties. Biochimica et Biophysica Acta 379, 201-206.

Quigley JD \& Drewry JJ (1998) Nutrient and immunity transfer from cow to calf pre- and postcalving. Journal of Dairy Science 81, 2779-2790.

Rainard P, Poutrel B \& Caffin JP (1984) Assessment of hemolytic and bactericidal complement activities in normal and mastitic bovine milk. Journal of Dairy Science 67, 614-619.

Rautemaa R \& Meri S (1999) Complement resistance mechanisms of bacteria. Microbes and Infections 1, 785-794.

Regester GO, Smithers GW, Mitchell IR, McIntosh GH \& Dionysis GH (1997) Bioactive factors in milk: natural and induced. In Milk Composition, Production and Biotechnology, pp. 119-132 [DJW Welch, SR Davis, AI Popay and CG Prosser, editors]. Wallingford UK: CAB International.

Reiter B (1985) Protective proteins in milk-biological significance and exploitation. IDF Bulletin 191, 1-35.

Reiter B \& Brock JH (1975) Inhibition of Escherichia coli by bovine colostrum and post-colostral milk I. Complementmediated bactericidal activity of antibodies to a serum susceptible strain of E. coli of the stereotype O 111. Immunology 28, 71-82.

Reiter B \& Oram JD (1967) Bacterial inhibitors in milk and other biological fluids. Nature 216, 328-330.

Roos N, Mahé S, Benamouzig R, Sick H, Rautureau J \& Tomé D (1995) 15-N-labeled immunoglobulins from bovine colostrum are partially resistant to digestion in human intestine. Journal of Nutrition 125, 1238-1244.

Staack C (1992) Bovine colostrum and protection of young animals. Berliner und Munchener Tierarztliche Wochenschrift 105, 219-224.

Stephan W, Dichtelmüller H \& Lissner R (1990) Antibodies from colostrum in oral immunotherapy. Journal of Clinical Chemistry and Clinical Biochemistry 28, 19-23.

Stott GH, Fleenor WA \& Kleese WC (1981) Colostral immunoglobulin in two fractions of first milking postpartum and five additional milkings. Journal of Dairy Science 64, 459465.

Stott GH, Lucas DO, (1989) Immunologically active whey fraction and recovery process. US Patent No 4834974, 30 May 1989.

Syväoja E-L, Ahola-Luttila HK, Kalsta H, Matilainen MH, Laakso S, Husu JR \& Kosunen TU (1994) Concentration of Campylobacter-specific antibodies in the colostrum of immunized cows. Milchwissenschaft 49, 27-31.

Tabel H (1996) Alternative pathway of complement in ruminants: role in infection. Veterinary Immunology and Immunopathology 54, 117-121.

Takahashi N, Eisenhuth G, Lee I, Laible N, Binion S \& Schachtele C (1992) Immunoglobulins in milk frim cows immunized with oral strains of Actinomyces, Prevotella, Porphyromonas and Fusobacterium. Journal of Dental Research 71, 1509-1515.

Triglia R (1980) Titers of nine complement components, conglutinin and $\mathrm{C} 3 \mathrm{~b}$-inactivator in adult and fetal bovine sera. Molecular Immunology 17, 729-740.

Turner WM (1996) Mannose-binding lectin - the pluripotent molecule of the innate immune system. Immunology Today $\mathbf{1 7}$ 532-540.

Virtanen S, Syväoja E-L, Loimaranta V \& Korhonen H (1998) Stability of activity of bovine colostrum derived anti-caries streptococci antibodies added to a UHT milk product. In European Dairy Experts Symposium: Dairying behind the Dikes, 15-18 September 1998 Arnhem, The Netherlands, Book of Abstracts, p. 38.

Walport M (1996) Complement. In Immunology, pp. 12-17 [I Roitt, J Brostoff, D Male and D Zack, editors]. London: Mosby.

Yolken RH, Losonsky G, Vonderfecht S, Leister F \& Wee S-B (1985) Antibody to human rotavirus in cow's milk. New England Journal of Medicine 312, 605-610.

Zinkernagel RM, Hilpert H, Gerber H, (1972) The digestion of colostral bovine immunoglobulins in infants. Experientia 28, 741. 